\title{
Article \\ Microvascular Density, Endothelial Area, and Ki-67 \\ Proliferative Index Correlate Each Other in Cat Post-Injection Fibrosarcoma
}

\author{
Rosa Patruno ${ }^{1}$, Giuseppe Passantino ${ }^{1} \mathbb{D}$, Carmelo Laface ${ }^{2,3}{ }^{\mathbb{D}}$, Antonella Tinelli ${ }^{1} \mathbb{D}$, Alfredo Zito ${ }^{4}$, \\ Roberta Ruggieri ${ }^{5}$, Francesco Luposella ${ }^{6}$, Pietro Gadaleta ${ }^{2}$, Mariarita Laforgia ${ }^{7}$, Luca Lacitignola ${ }^{8}$ (D), \\ Michele Ammendola ${ }^{9}$ (D), Girolamo Ranieri ${ }^{2, *(D)}$ and Nicola Zizzo ${ }^{1}$ (D)
}

\section{check for}

updates

Citation: Patruno, R.; Passantino, G.; Laface, C.; Tinelli, A.; Zito, A.;

Ruggieri, R.; Luposella, F.; Gadaleta,

P.; Laforgia, M.; Lacitignola, L.; et al.

Microvascular Density, Endothelial

Area, and Ki-67 Proliferative Index

Correlate Each Other in Cat

Post-Injection Fibrosarcoma. Cells

2021, 10, 31. https://doi.org/

10.3390/cells10010031

Received: 6 November 2020

Accepted: 24 December 2020

Published: 28 December 2020

Publisher's Note: MDPI stays neutral with regard to jurisdictional clai$\mathrm{ms}$ in published maps and institutional affiliations.

Copyright: $\odot 2020$ by the authors. Licensee MDPI, Basel, Switzerland. This article is an open access article distributed under the terms and conditions of the Creative Commons Attribution (CC BY) license (https:// creativecommons.org/licenses/by/ $4.0 /)$.
1 Department of Veterinary Medicine, Section of Veterinary Pathology and Comparative Oncology, University of Bari "Aldo Moro", Strada p.le per Casamassima, km 3, 70010 Valenzano, Bari, Italy; rosavet@libero.it (R.P.); giuseppe.passantino@uniba.it (G.P.); antonella.tinelli@uniba.it (A.T.); nicola.zizzo@uniba.it (N.Z.)

2 Interventional and Medical Oncology Unit, IRCCS Istituto Tumori "G. Paolo II", 70124 Bari, Italy; carmelo.laface@gmail.com (C.L.); cd.gadaleta@gmail.com (P.G.)

3 Department of Biomedical Sciences and Clinical Oncology, University of Bari Aldo Moro, 10124 Bari, Italy

4 Pathology Unit, IRCCS Istituto Tumori “G. Paolo II", 70124 Bari, Italy; fazito@libero.it

5 Cardiology Unit, University of Bari “Aldo Moro", 70124 Bari, Italy; roberta.ruggieri@gmail.com

6 Direction Départementale de la Cohésion Sociale et de la Protection des Populations des VOSGES (DDCSPP88), 88080 Vittel, France; francescoluposella@hotmail.it

7 Pharmacy Unit, IRCCS Istituto Tumori “G. Paolo II", 70124 Bari, Italy; m.laforgia@oncologico.bari.it

8 Department of Emergency and Organ Transplantation, University of Bari 'Aldo Moro', Strada p.le per Casamassima, km 3, 70010 Valenzano, Bari, Italy; luca.lacitignola@uniba.it

9 Department of Health Science, Digestive Surgery Unit, University "Magna Graecia" Medical School, Viale Europa, Germaneto, 88100 Catanzaro, Italy; michele.ammendola@libero.it

* Correspondence: giroran@tiscali.it

Abstract: Soft tissue sarcomas are a large group of different tumor types both in humans and in animals. Among them, fibrosarcoma is the most frequent malignant mesenchymal tumoral form in cats, representing up to $28 \%$ of all cat skin tumors, while human fibrosarcoma, fortunately, only represents $5 \%$ of all sarcomas and $0.025 \%$ of the world-wide burden of tumors. This low incidence in humans leads to consideration of this group of tumoral diseases as rare, so therapeutic options are few due to the difficulty of starting clinical trials. In this context, the identification of research models for fibrosarcomas could be of great interest to deepen knowledge in this field and recognize new or possible biological pathways involved in tumor progression and metastasis. Angiogenesis is considered a fundamental scattering cause of tumor aggressiveness and progression in all forms of cancer, but only a few research parameters were developed and reported to express them quantitatively and qualitatively. The role in angiogenesis of microenvironmental stromal cells, such as fibroblasts, lymphocytes, mast cells, and macrophages, was largely demonstrated since this topic was first approached, while quantification of new vessels and their blood capacity in tumoral area is a relatively recent approach that could be well developed thanks to expertise in immunohistochemistry and image analysis. In this paper, a crossing study evaluating microvascular density (MVD), endothelial area (EA), and Ki-67 proliferative index was reported for a series of formalin-fixed and paraffin-embedded tissue samples from 99 cat patients, affected by cat post-injection fibrosarcoma, by using a till $\times 400$ magnification light microscopy. We aim to demonstrate that cat pets may be considered a useful animal model for better studying the correspondent human diseases and we report, for the first time to our knowledge, experimental data in terms of correlation among MVD, EA, and Ki-67 strictly involved in aggressiveness and tumoral progression.

Keywords: angiogenesis; cat fibrosarcoma; endothelial area; immunohistochemistry; Ki-67 proliferation index; microvascular density 


\section{Introduction}

Pet animals, cats and dogs, have been largely used as models for oncological research since the spread of the "one medicine and pathology approach" to cancer $[1,2]$. With special regard to soft tissue tumors, cat post-injection fibrosarcoma (CPIFI) is certainly a useful model to deepen knowledge about sarcomas [3-6]. From a clinical point of view, fibrosarcoma (FI), which originates from fibroblasts, is the most common malignant mesenchymal tumor in cats, representing $14 \%$ to $28 \%$ of all cat skin tumors, with an onset average age of 12 years [7]. Subcutaneous FIs frequently arise on the trunk and distal parts of the limbs, while dermal FIs hit the pinnae and digits in most cases [8], but these tumors often recur and metastasize to distant organs, inducing death of the animal [9]. To perform their metastatic ability, sarcoma cells need to penetrate blood vessels and, in turn, proliferate in the chosen metastatic site. An increased microvascular bed, depicted by the angiogenesis processes, facilitates the metastatic spread [10]. With special regard to CPIFI, its sprouting at the vaccination site was previously reported $[8,11]$. From a pathogenetic point of view, literature data correlate stromal infiltrate cells to CFI development [12,13], underlining that microenvironmental stromal cells, such as fibroblasts, lymphocytes, mast cells, and macrophages, sustain angiogenesis in several human and animal malignancies [14-24]. Due to its origin from fibroblasts, CPIFI has a rich stromal cell infiltrate which is supposed to be responsible for the pathogenesis of the tumor [25]. It is also noteworthy that the number of tumor cell mitoses per field was considered a parameter of the biological aggressiveness of sarcoma, as for other solid tumors [26,27]. A higher Ki-67 proliferative index, being the expression of CPIFI malignancy and aggressiveness, should be accompanied by a higher neovascularization process $[16,28]$. For the first time in the literature, Couto et al. evaluated the correlation between the proliferative activity, evaluated as Ki-67 positive tumoral fibroblastic cells, and angiogenesis in terms of microvascular density (MVD) in 60 CPIFIs in 2002. However, no data are published regarding the correlation between the proliferative activity and angiogenesis both in terms of microvascular density (MVD) and endothelial area (EA) as pathologic cellular pathways in CPIFI development $[18,29,30]$. MVD represents the number of immunostained old and new vessels, while EA is the immunostained vascular area in a microscopic field that is the expression of vessels' blood capacity and diameters. In combination, the two research parameters fuse different quantitative aspects of angiogenesis. The main endpoint of this research was to explore this; to this aim, we studied a series of 99 CPIFIs in terms of proliferative index of tumoral fibroblastic cells and angiogenesis using immunohistochemistry and image analysis systems. Interestingly, thanks to its higher incidence compared to human FI, although its development is scattered by an inflammatory reaction to the injection site, CPIFI might be considered a spontaneous model to evaluate angiogenesis and antiangiogenesis pharmacological strategy, which could be translated to humans.

\section{Patients and Methods}

\subsection{Patients}

A series of formalin-fixed and paraffin-embedded tissue samples obtained from 99 cases of CPIFI were employed. Patients were observed at the Department of Veterinary Medicine of Bari University and, after complete clinical examination, biopsy for each cat was performed. In the next step, the cats with confirmed histological diagnosis of FI were surgically treated [31]. Table 1 shows the patients' characteristics.

\subsection{Hematoxylin-Eosin and Immunohistochemistry}

Histological diagnosis was performed on serial slides for each tumor sample, stained with hematoxylin-eosin method (Figure 1A-C). According to Couto's classification, the cases were defined as follows: $32(32.3 \%)$ were G1, corresponding to well differentiated, $38(38.4 \%)$ were G2, corresponding to intermediately differentiated, and $29(29.3 \%)$ were G3, corresponding to poorly differentiated CPIFIs [26,27]. For the evaluation of MVD, EA, and Ki-67 proliferative index, a three-layer biotin-avidin-peroxidase system, as previously 
described, was adopted $[16,18,28]$. Briefly, $5 \mu \mathrm{m}$ thin serial sections of formalin-fixed and paraffin-embedded were cut for each tissues sample. For antigen retrieval, the obtained slides were processed with a microwave oven at 500 watts for $10 \mathrm{~min}$; then, the endogenous peroxidase enzyme was inhibited with a $3 \%$ hydrogen peroxide solution. Soon after, the slides were incubated with the following primary antibodies:

(a) The rabbit polyclonal anti-factor VIII-related antigen (FVIII-RA) antibody (dilution, 1:50; Dako, Glostrup, Denmark) for $1 \mathrm{~h}$ at room temperature;

(b) The MIB-1 antibody to Ki-67 nuclear proliferation antigen (dilution, 1:100; MIB-1; Immunotech, Inc., Marseilles, France) for $1 \mathrm{~h}$ at room temperature.

Table 1. Patients' characteristics.

\begin{tabular}{cc}
\hline Variable & No. of Patients \\
\hline Age years & 34 \\
$<8$ & 65 \\
$>8$ & \\
Gender & 44 \\
Male & 55 \\
Female & Interscapular area (40) \\
& Dorsal area (21) \\
& Costal area (15) \\
Tumor site & Left Scapular area (12) \\
& Right Scapular area (7) \\
& Left neck (2) \\
& Thigh sx (2) \\
Histological grade & 32 \\
G2 & 38 \\
G3 & 29 \\
\hline Average time from vaccine injection to diagnosis & 2.1 years \\
\hline
\end{tabular}

Immunoreactivity was evidenced by employing a biotinylated secondary antibody, the avidin-biotin-peroxidase complex (LPS, K0640, Dako, Glostrup, Denmark), and the chromogen 3-amino-9-ethyl carbazole (Dako, Glostrup, Denmark). Nuclear counterstaining was performed with Gill's haematoxylin (Polysciences, Warrington, PA, USA) for each tissue sample [32]. An additional slide from each cat without the primary anti-factor VIII antibody was used as negative control. For the Ki-67 proliferative index, sections from normal feline intestines were used for each experiment and the corresponding epithelium was considered negative if it lacked immunostaining after utilization of the MIB-1 primary antibody.

Feline granulation tissue specimens were used as a positive control for blood vessels. Regarding the MIB-1 antibody, positive controls consisted of normal feline small intestines, because intestinal crypts are considered sites of proliferation.

\subsection{Image Analysis}

MVD was identified according to the modified Weidner's method [33]. Weidner's method provides that any brown-staining endothelial cell or endothelial-cell cluster clearly separated from adjacent microvessels, tumor cells, and other connective-tissue elements are considered single, countable microvessels. Vessel lumens, although usually present, are not necessary for a structure to be defined as a microvessel, and red cells are not used to define a vessel lumen. Each count is expressed as the highest number of microvessels identified within any $200 \times$ or $400 \times$ field. All counts are performed by two investigators using a double-headed light microscope simultaneously; both operators agreed on what constituted a single microvessel before any vessel was included in the count [34]. In our study, we employed a modified technique; the slides were morphometrically evaluated 
independently by two investigators with the help of an image analysis system (Quantimet 500 Leica). To be specific, first of all, we selected vascular "hot spots" for each tumor grade at low magnification $\times 100$ at light microscopy (Leica DM 4000). Then, ten fields were randomly selected at $\times 400$ magnification in a $0.19 \mathrm{~mm}^{2}$ area (Figure $2 \mathrm{~A}-\mathrm{C}$ ).

Angiogenesis was also evaluated in terms of EA in a semiautomated approach, delimiting the perimeter of the single vessel and then calculating the corresponding area by the software of the image analysis system, both for each vessel and then for all vessels in the observed $\times 400$ magnification in a $0.19 \mathrm{~mm}^{2}$ area (Figure $3 \mathrm{~A}-\mathrm{C}$ ) $[16,28,32-38]$.

In the serial section, $\mathrm{Ki}-67$ proliferative index evaluation was determined in the same area of MVD, and only specific nuclear staining was considered. The number of MIB-1 positively stained nuclei tumor cells was counted at $\times 400$ magnification in a $0.19 \mathrm{~mm}^{2}$ area (Figure $4 \mathrm{~A}-\mathrm{C}$ ). The fraction of Ki-67 positive cells was calculated as the ratio of positively stained tumor cells and all tumor cells observed in the analyzed microscopic field $[18,29,30]$.

All the above tissue parameters were independently evaluated by two operators (authors NZ and AZ, veterinary and human pathologists, respectively), with a correlation coefficient of $\geq 90 \%$.

\subsection{Statistical Analysis}

Mean value \pm standard deviations (S.D.) was evaluated for MVD, EA, Ki-67, expression in G1, G2 and G3 CPIFI subgroups. The significance of differences in terms of MVD, EA, and Ki-67 means between G1 versus (vs.) G2, G2 vs. G3, and G3 vs. G1 tumor groups was performed by one-way ANOVA test. Correlations among MVD, EA, and Ki-67 were calculated using Pearson's ( $r$ ) analysis. All statistical analyses were performed with the SPSS statistical software package (SPSS, Inc., Chicago, IL, USA). 


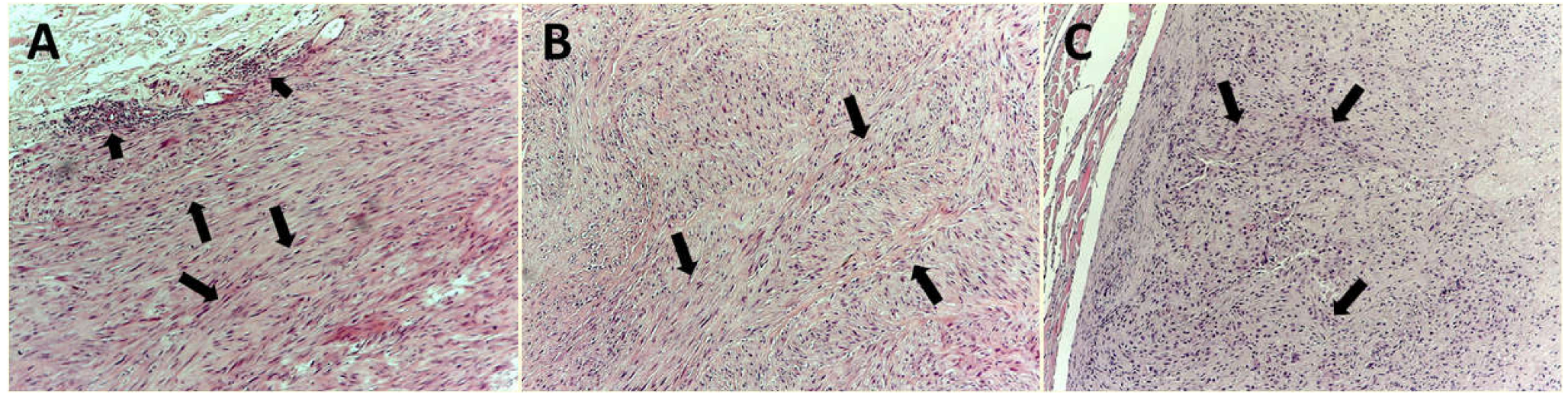

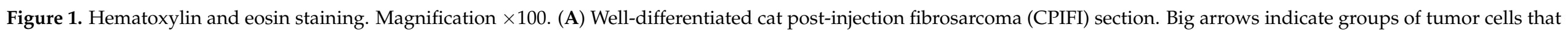

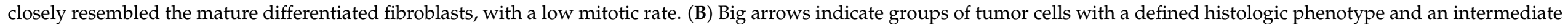
mitotic rate. (C) Big arrows indicate groups of poorly differentiated tumor cells with a high mitotic rate.

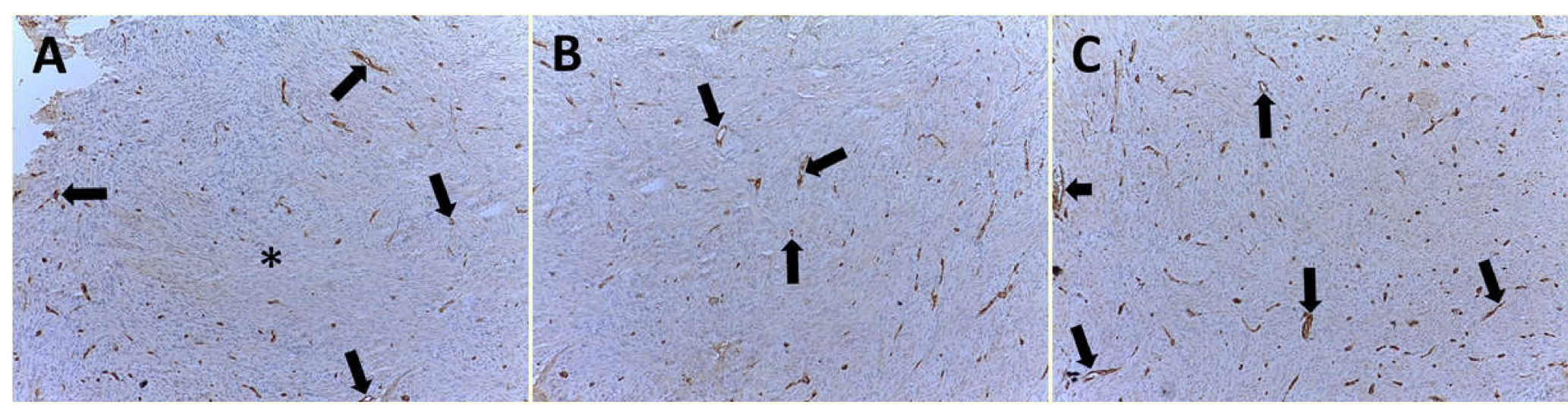

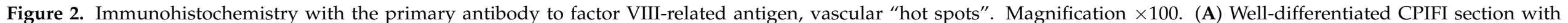

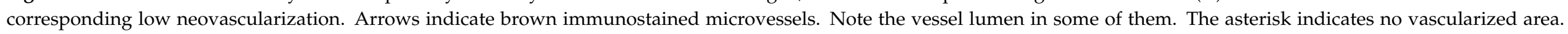

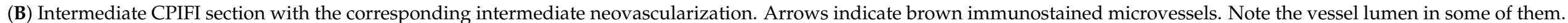

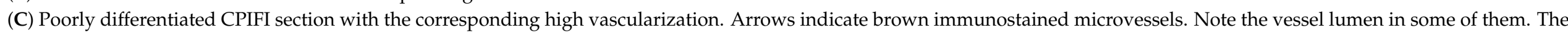
small arrow indicates a microvessel with circulating cells in its lumen as an internal positive control. 


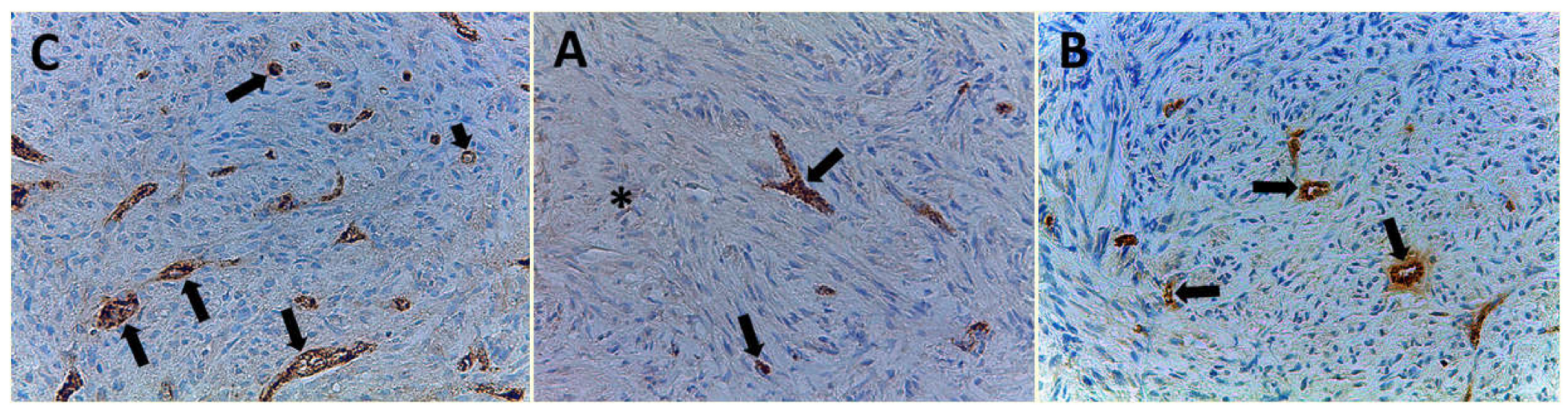

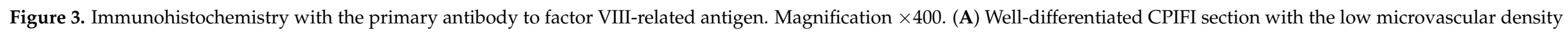

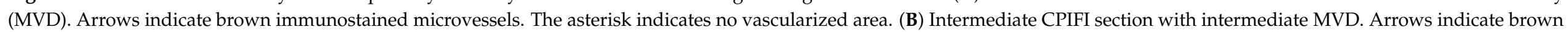

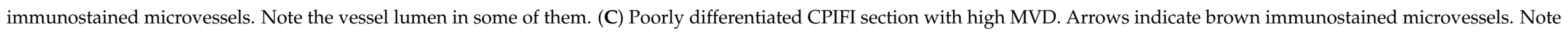
the vessel lumen in some of them. The small arrow indicates a microvessel with circulating cells in its lumen as an internal positive control.

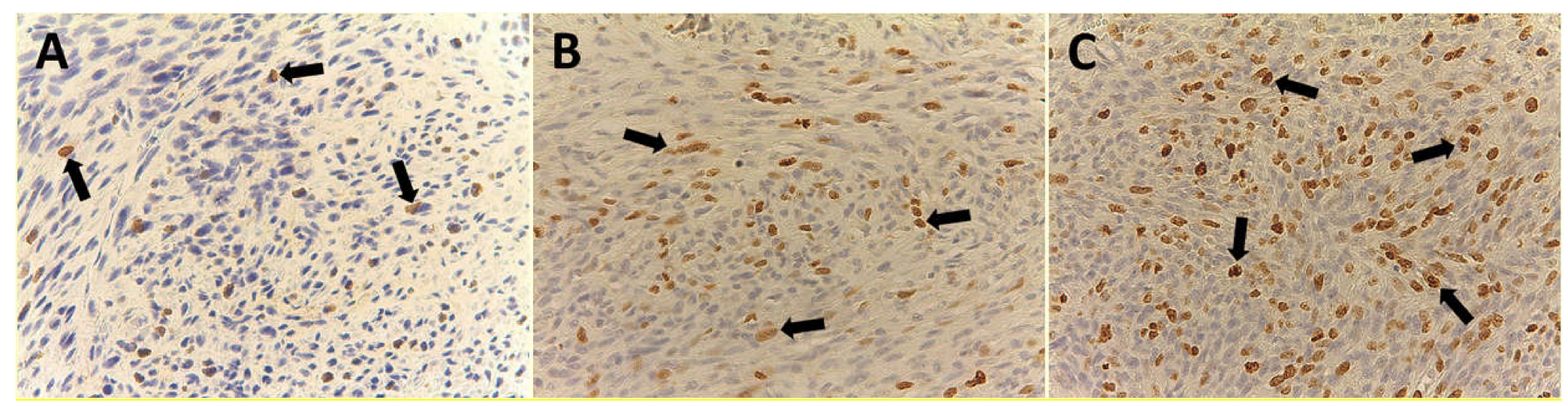

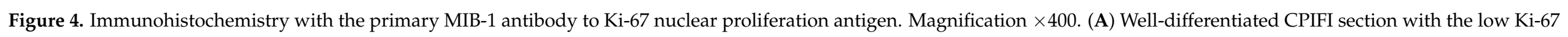

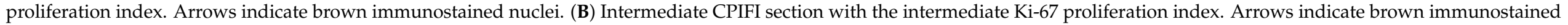
nuclei. (C) Poorly differentiated CPIFI section with the high Ki-67 proliferation index. Arrows indicate brown immunostained nuclei. 


\section{Results}

All 99 samples from CPIFI were eligible for the evaluation of both MVD and EA. The FVIII-RA immunostaining showed good intensity on endothelial cells with no or low perivascular background (Figures 2 and 3). Table 2 shows the mean values of MVD and EA on tissue sections of CPIFI grouped according to the Couto's classification [26]. Significant differences in terms of MVD re demonstrated between G1 vs. G3 $(9 \pm 4$ S.D. vs. $25 \pm 9$ S.D.; $\mathrm{f}=282.80$, $\left.p=3.53 \times 10^{-24}\right)$ and G2 vs. G3 (12 \pm 5 S.D. vs. $25 \pm 9$ S.D.; $\left.\mathrm{f}=196.54, p=2.53 \times 10^{-21}\right)$ (Table 2). In the same manner, significant differences in terms of EA were evident between G1 vs. G3 $\left(81.96 \times 10^{-2} \pm 20.30 \mu \mathrm{m}^{2}\right.$ S.D. vs. $151.77 \times 10^{-2} \pm 33.52 \mu \mathrm{m}^{2}$ S.D.; $\mathrm{f}=288.75$, $\left.p=2.12 \times 10^{-24}\right)$ and G2 vs. G3 $\left(83.01 \times 10^{-2} \pm 25.48 \mu \mathrm{m}^{2}\right.$ S.D. vs. $151.77 \times 10^{-2} \pm$ $33.52 \mu \mathrm{m}^{2}$ S.D.; $\mathrm{f}=247.24, p=7.79 \times 10^{-24}$ ) (Table 2). In the case of Ki-67-positive fraction in terms of MIB-1-positive nucleus, significant differences were found between G1 vs. G3 (9.35 \pm 5.82 S.D. vs. $44.33 \pm 17.91$ S.D.; $\left.\mathrm{f}=340.83, p=3.41 \times 10^{-26}\right)$ and G2 vs. G3 $\left(15.16 \pm 8.91\right.$ S.D. vs. $44.33 \pm 17.91$ S.D.; $\left.\mathrm{f}=214.29, p=2.97 \times 10^{-22}\right)$ (Table 2). The aboveanalyzed tissue biomarkers were significantly crosslinked each other in each subgroup of malignancy grade $(\mathrm{G} 1, \mathrm{G} 2$, and $\mathrm{G} 3$ respectively, $\mathrm{r}$ ranging from 0.41 to $0.78, p$ ranging from 0.01 to 0.03 , as shown in Figure 5).

Table 2. MVD, endothelial area (EA), and Ki-67-positive fraction indexes means \pm standard deviations analyzed as a function of CPIFI malignancy grade. The significance of differences in terms of MVD, EA, and Ki-67 means between G1 vs. G2, G2 vs. G3, and G3 vs. G1 tumor groups was performed by one-way ANOVA test.

\begin{tabular}{|c|c|c|c|}
\hline No. of Patients (\%) & MVD $\times 400$ & EA $\times 400$ & $\begin{array}{c}\text { Ki-67 Index in Terms of } \\
\text { MIB-1 Positive Nuclei } \times 400\end{array}$ \\
\hline G1 (32/99-32.3\%) & $9 \pm 4$ & $81.96 \times 10^{-2} \pm 20.30 \mu \mathrm{m}^{2}$ & $9.35 \pm 5.82$ \\
\hline G2 $(38 / 99-38.4 \%)$ & $12 \pm 5$ & $83.01 \times 10^{-2} \pm 25.48 \mu \mathrm{m}^{2}$ & $15.16 \pm 8.91$ \\
\hline G3 (29/99-29.3\%) & $25 \pm 9$ & $151.77 \times 10^{-2} \pm 33.52 \mu \mathrm{m}^{2}$ & $44.33 \pm 17.91$ \\
\hline \multirow[t]{3}{*}{ ANOVA test } & $\begin{array}{l}\text { G1 vs. G2 } \\
\text { n.s. }\end{array}$ & $\begin{array}{l}\text { G1 vs. G2 } \\
\text { n.s. }\end{array}$ & $\begin{array}{l}\text { G1 vs. G2 } \\
\text { n.s. }\end{array}$ \\
\hline & $\begin{array}{c}\text { G1 vs. G3 } \\
\mathrm{f}=282.80 \\
p=3.53 \times 10^{-24}\end{array}$ & $\begin{array}{c}\text { G1 vs. G3 } \\
\mathrm{f}=288.75 \\
p=2.12 \times 10^{-24}\end{array}$ & $\begin{array}{c}\text { G1 vs. G3 } \\
\mathrm{f}=340.83 \\
p=3.41 \times 10^{-26}\end{array}$ \\
\hline & $\begin{array}{c}\mathrm{G} 2 \text { vs. G3 } \\
\mathrm{f}=196.54 \\
p=2.53 \times 10^{-21}\end{array}$ & $\begin{array}{c}\text { G2 vs. G3 } \\
\mathrm{f}=247.24 \\
p=7.79 . \times 10^{-24}\end{array}$ & $\begin{array}{c}\text { G2 vs. G3 } \\
\mathrm{f}=214.29 \\
p=2.97 \times 10^{-22}\end{array}$ \\
\hline
\end{tabular}




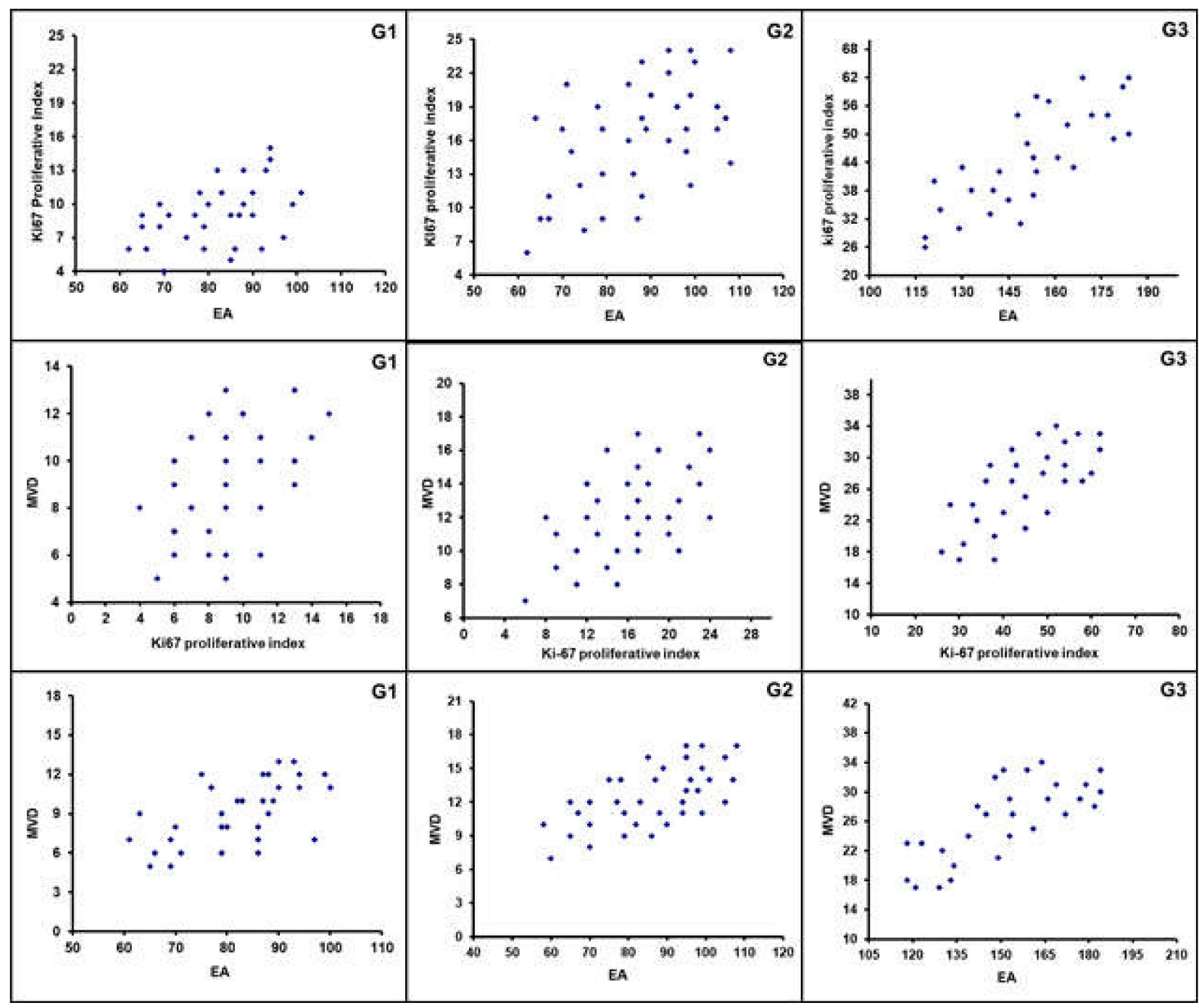

Figure 5. Correlation analyses between: Ki67 and MVD, G1 ( $\mathrm{r}=0.42)$; Ki67 and MVD, G2 ( $\mathrm{r}=0.51)$; Ki67 and MVD, G3 ( $r=0.78)$; MVD and Ki67, G1 ( $r=0.48)$; MVD and Ki67, G2 ( $r=0.54)$; MVD and Ki67, G3 ( $r=0.71)$; MVD and EA, G1 $(\mathrm{r}=0.60)$; MVD and EA, G2 ( $\mathrm{r}=0.65)$; MVD and EA, G3 $(\mathrm{r}=0.75)$.

\section{Discussion}

Soft tissue sarcomas are malignancies deriving from mesenchymal tissues and, though sharing a common origin, are a large group of different tumor types. The low frequency of human sarcomas, with an incidence of about $0.5-1 \%$ of the annual burden of all human malignancies $[39,40]$, limits research to a very little series of cases for each histological type. In particular, human FI constitutes $5 \%$ of all sarcomas, representing $0.025 \%$ of annual burden in the world [41]. Despite the progress in multimodality treatment, the prognosis for all soft tissue sarcomas is still poor [42]. Consequently, the availability of a possible spontaneous animal sarcoma model sharing similar pathological and biological features with humans could be very useful to clarify both the angiogenetic and proliferative pathways for comparative and translational rebound [18,43-48]. To this regard, the role of angiogenesis, in terms of MVD and EA, is important for primary tumor growth, invasion and metastasis $[32,37,47,49,50]$. Angiogenesis is sustained by several proangiogenic factors and, among them, vascular endothelial growth factor (VEGF) is the most involved and biologically characterized, correlating with malignant development and progression in several human and animal malignancies [51-59]. In particular, in the in vivo preclinical study performed in fibrosarcoma HT1080-conditioned medium cell line, experimental 
data demonstrated that the conditioned medium expressed a higher VEGF concentration if compared to a human bone marrow-derived mesenchymal stem cell culture, used as control [60]. In addition, the injection of HT1080-conditioned medium into mouse ischemic limbs significantly induced capillary density and blood perfusion when compared with the injection of fresh medium. Interestingly, the reduction of angiogenesis, tumor growth, and metastases following the administration of the anti-VEGF antibody [61-64] in a xenograft model of human fibrosarcoma HT1080 cell line was previously reported. The involvement of angiogenesis in murine FI experimental model was also suggested by Lee et al., who demonstrated the role of alpha-Tumor Necrosis Factor in stimulating angiogenesis [65]. From a therapeutic point of view, angiostatin cDNA coding from mouse angiostatin into murine T241 fibrosarcoma cells is able to inhibit angiogenesis and tumor growth in C57B16/J mice, confirming the role of neovascularization in this preclinical model [53]. Finally, the simultaneous overexpression of PDGF-BB and FGF2 in murine FI led to the formation of high-density immature microvessels without pericytes, strongly suggesting the role of angiogenesis in FI models [66]. In summary, these preclinical and laboratory animal studies indicate that the angiogenetic process is one of the fundamental scattering causes for FI growth and progression [15]. In parallel, the proliferative index of tumoral cells evaluated in terms of Ki-67-immunostained nuclei by MIB- 1 antibody was correlated with poor prognosis in several human and animal tumors. The above-reported data are in harmony with our results. In fact, we demonstrated that an enhanced angiogenesis, evaluated through MDV and EA values, is concomitant to tumoral increased malignancy, that is, more aggressive and proliferative tumors induce more active angiogenesis. Moreover, more undifferentiated forms develop a higher tumor ability to spread metastases.

For the first time in the literature, Couto et al. (2002) evaluated the correlation between proliferative activity in terms of Ki-67-positive tumoral fibroblastic cells and angiogenesis in terms of MVD in 60 CPIFIs [26]. However, to our knowledge, no data were reported regarding the correlation between proliferative activity and angiogenesis, both in terms of MVD and EA, as pathologic cellular pathways in CPIFI development. Both studies demonstrate with objective data that, in a FI spontaneous animal model, angiogenetic processes are directly related to malignancy degrees. This concept feeds a huge research area on angiogenetic drugs to be shared between animals and humans, with angiogenesis and mitosis growing in number related to negative prognosis, as indicated by Couto's grading in FI. Ki-67 is a useful measure of cell mitotic activity, being higher in G3 with respect to G2 and in G3 with respect to G1 in our 99 experimental CPIFIs.

However, some differences can be found between our study and Couto's [26]. First of all, we performed an evaluation on a wider case series (90 vs. 60 CPIFIs). Secondly, we introduced another tissue parameter as a key element of the discussion, endothelial area, which corresponds to the immunostained vascular area in a microscopic field, that is, the expression of vessels' blood capacity and diameters. Combined data of MVD and EA give different quantitative aspects of angiogenesis. Moreover, we applied the modified Weidner's method for the quantification of MVD (see Sections 2 and 2.3), while Couto employed another method. Tissue sections stained with anti-CD31 antibody were scanned at $200 \times$ magnification to select the areas of highest vascularization. From these areas, three nonoverlapping fields were identified and captured using a digital camera connected to a microscope and saved on a computer. These same areas were then identified in the adjacent sections stained with factor VIII antibody and imaged in the same manner. A coloured filter was developed to allow specific detection of the chromogen on CD31- and factor VIII-stained slides. Chromogen was detected on slides using a computer and image manipulation software. With this software, pixels stained with chromogen were selected, converted to black, and transferred to a white background to create a binary image. The total number of black and white pixels in each image was quantified using an image analysis program. Vascular density was calculated by dividing the total number of black pixels by the total number of pixels within the image. Total vascular density was the mean of values obtained for three images captured from each tissue examined and was expressed as a percentage (in our study we evaluated the count directly). 
Neovascularization, expressed as a percentage, was determined as the absolute value of the total vascular density derived from factor VIII-rag-stained sections minus the vascular density derived from CD31-stained sections.

Regarding the Ki-67 proliferative index evaluation, there are three main differences between Couto's method and our technique:

(1) According to Couto's method, images of six nonoverlapping, $400 \times$ magnification fields along the periphery (growth fronts or hot spots) of the tumor were captured. Instead, we performed Ki-67 proliferative index evaluation in the adjacent sections with respect to the MVD count, selecting images of ten nonoverlapping, $400 \times$ magnification fields.

(2) According to Couto's method, the number of fields was calculated so that a minimum of 1000 cells was counted per specimen. The total number of cells counted per field varied depending on the cellular density of each tumor. Instead, we performed the evaluation without a minimum cut-off of cells.

(3) According to Couto's method, values obtained for positive and negative cells were summed and the proliferative fraction of peripheral regions of each tumor was determined to be the number of cells immunolabeled with MIB-1 (red) divided by the total number of cells counted per tumor. For comparison, the same procedure was applied to six nonoverlapping, $400 \times$ fields within the central region of each tumor. Instead, in our study, the fraction of Ki-67-positive cells was calculated as the ratio of positively stained tumor cells and all tumor cells observed in the analyzed microscopic field.

Our results demonstrate a statistically significant association among increased angiogenesis, proliferation, and malignancy degree in FI through concrete and objective parameters, i.e., MDV, EA, and Ki-67 values; a higher proliferation index induced increased tumoral vascularization and malignancy. These data were in agreement with our and other previously published studies on human malignancies $[28,67,68]$. With special regard to our data, we already demonstrated that MVD, EA, and Ki-67 proliferative index were significantly correlated to each other in pancreatic ductal adenocarcinoma patients [28].

Despite people not sharing the same high propensity for inflammation-associated sarcoma development as in feline injection-site fibrosarcoma, CPIFI has a high incidence compared to humans but shares a similar marked tendency to metastasize, in particular to the lungs [69,70]. Moreover, from a well-known biological point of view, human fibrosarcoma can grow through tumoral angiogenesis. In fact, Couto [26] already demonstrated that G3 CPIFIs, with a higher metastatic capacity, were associated with a higher angiogenesis in terms of total microvascular density with respect to G1 and G2 CPIFIs. In our study, we confirmed that MVD was higher in G3 CPIFIs with respect to G1 and G2 ones. This aspect suggests that angiogenesis can be considered an interspecies mechanism for tumor growth and progression.

Moreover, it is well known that in human fibrosarcomas, $\mathrm{Ki}-67$ proliferative index is correlated with a higher malignant grade and a greater tendency to metastasize. Similarly, Couto already demonstrated that Ki-67 proliferative index is higher in G3 CPIFI with respect to G1 and G2 ones, with a greater tendency to metastasize.

In summary, the literature data demonstrated that CPIFI and human fibrosarcoma share angiogenetic and proliferative pathways for their tumor growth and progression. As a consequence, we suggest that cat FI spontaneous model might be a good preclinical background for evaluating novel treatments, combining angiogenetic inhibitors and antiproliferative chemotherapeutic drugs before further translating to humans.

Author Contributions: Conceptualization, R.P., G.R. and N.Z.; methodology, R.R., M.A., N.Z., R.P. and A.Z.; software G.P., A.T., P.G.; validation, C.L.; formal analysis, L.L.; investigation, G.R.; resources, M.L. and C.L.; data curation, F.L.; writing—original draft preparation, C.L., M.L. and G.R.; writingreview and editing, M.L.; visualization, N.Z.; project administration, M.A., C.L. and G.R.; supervision, G.R. All authors have read and agreed to the published version of the manuscript.

Funding: This research received no external funding. 
Institutional Review Board Statement: This is a retrospective investigation on animal tissue samples by cats hospitalized for diagnosis, which underwent neither treatments nor procedures different from routine practice. Therefore, for our scientific purpose, no ethical statement was needed.

Informed Consent Statement: Informed consent was obtained from all the patients' owners involved in the study.

Data Availability Statement: The data presented in this study are available on request from the corresponding author.

Acknowledgments: We would like to thank Lo Presti Giuseppe for the excellent technical assistance.

Conflicts of Interest: The authors have no relevant affiliation or financial involvement with any organization or entity with a financial interest or financial conflict with the subject matter or materials discussed in the manuscript.

\section{References}

1. Paoloni, M.; Khanna, C. Translation of new cancer treatments from pet dogs to humans. Nat. Rev. Cancer 2008, 8, 147-156. [CrossRef]

2. Di Cerbo, A.; Palmieri, B.; De Vico, G.; Iannitti, T. Onco-epidemiology of domestic animals and targeted therapeutic attempts: Perspectives on human oncology. J. Cancer Res. Clin. Oncol. 2014, 140, 1807-1814. [CrossRef] [PubMed]

3. Esplin, D.G.; McGill, L.D.; Meininger, A.C.; Wilson, S.R. Postvaccination sarcomas in cats. J. Am. Vet. Med. Assoc. 1993, 202, 1245-1247. [PubMed]

4. Kass, P.H.; Barnes, W.G., Jr.; Spangler, W.L.; Chomel, B.B.; Culbertson, M.R. Epidemiologic evidence for a causal relation between vaccination and fibrosarcoma tumorigenesis in cats. J. Am. Vet. Med Assoc. 1993, 203, 396-405. [PubMed]

5. Macy, D.W. The potential role and mechanisms of FeLV vaccine-induced neoplasms. Semin. Vet. Med. Surg. 1995, $10,234-237$.

6. Martin, M. Vaccine-associated fibrosarcoma in a cat. Can. Vet. J. 2003, 44, 660-663.

7. Martano, M.; Morello, E.; Buracco, P. Feline injection-site sarcoma: Past, present and future perspectives. Vet. J. 2011, 188, 136-141. [CrossRef]

8. Doddy, F.D.; Glickman, L.T.; Glickman, N.W.; Janovitz, E.B. Feline fibrosarcomas at vaccination sites and non-vaccination sites. J. Comp. Pathol. 1996, 114, 165-174. [CrossRef]

9. Kliczkowska, K.; Jankowska, U.; Jagielski, D.; Czopowicz, M.; Sapierzyński, R. Epidemiological and morphological analysis of feline injection site sarcomas. Pol. J. Vet. Sci. 2015, 18, 313-322. [CrossRef]

10. Rocchi, L.; Caraffi, S.; Perris, R.; Mangieri, D. The angiogenic asset of soft tissue sarcomas: A new tool to discover new therapeutic targets. Biosci. Rep. 2014, 34, e00147. [CrossRef]

11. Vascellari, M.; Melchiotti, E.; Bozza, M.A.; Mutinelli, F. Fibrosarcomas at presumed sites of injection in dogs: Characteristics and comparison with non-vaccination site fibrosarcomas and feline post-vaccinal fibrosarcomas. J. Vet. Med. Aphysiologypathol. Med. 2003, 50, 286-291. [CrossRef] [PubMed]

12. Macy, D.W.; Hendrick, M.J. The Potential Role of Inflammation in the Development of Postvaccinal Sarcomas in Cats. Vet. Clin. N. Am. Small Anim. Pract. 1996, 26, 103-109. [CrossRef]

13. Saba, C.F. Vaccine-associated feline sarcoma: Current perspectives. Vet. Med. 2017, 8, 13-20. [CrossRef] [PubMed]

14. Patruno, R.; Marech, I.; Zizzo, N.; Ammendola, M. c-Kit expression, angiogenesis, and grading in canine mast cell tumour: A unique model to study c-Kit driven human malignancies. BioMed Res. Int. 2014, 2014, 730246. [CrossRef]

15. Girolamo, R. Editorial [ Hot Topic: Targeting Tumor Angiogenesis: An Update (Guest Editor: Girolamo Ranieri)]. Curr. Med. Chem. 2012, 19, 937. [CrossRef]

16. Ranieri, G.; Patruno, R.; Lionetti, A.; Di Summa, A.; Mattioli, E.; Bufo, P.; Pellecchia, A.; Ribatti, D.; Zizzo, N. Endothelial area and microvascular density in a canine non-Hodgkin's lymphoma: An interspecies model of tumor angiogenesis. Leuk. Lymphoma 2005, 46, 1639-1643. [CrossRef]

17. Berse, B.; Hunt, J.A.; Diegel, R.J.; Morganelli, P.; Yeo, K.; Brown, F.; Fava, R.A. Hypoxia augments cytokine (transforming growth factor-beta (TGF-beta) and IL-1)-induced vascular endothelial growth factor secretion by human synovial fibroblasts. Clin. Exp. Immunol. 1999, 115, 176-182. [CrossRef]

18. Patruno, R.; Zizzo, N.; Zito, A.F.; Catalano, V.; Valerio, P.; Pellecchia, V.; D’Errico, E.; Mazzone, F.; Ribatti, D.; Ranieri, G. Microvascular density and endothelial area correlate with Ki-67 proliferative rate in the canine non-Hodgkin's lymphoma spontaneous model. Leuk. Lymphoma 2006, 47, 1138-1143. [CrossRef]

19. Crawford, Y.; Kasman, I.; Yu, L.; Zhong, C.; Wu, X.; Modrusan, Z.; Kaminker, J.; Ferrara, N. PDGF-C mediates the angiogenic and tumorigenic properties of fibroblasts associated with tumors refractory to anti-VEGF treatment. Cancer Cell 2009, 15, 21-34. [CrossRef]

20. Marech, I.; Ammendola, M.; Gadaleta, C.; Zizzo, N.; Oakley, C.; Gadaleta, C.D.; Ranieri, G. Possible biological and translational significance of mast cells density in colorectal cancer. World J. Gastroenterol. 2014, 20, 8910-8920. [CrossRef]

21. Sammarco, G.; Gadaleta, C.D.; Zuccalà, V.; Albayrak, E.; Patruno, R.; Milella, P.; Sacco, R.; Ammendola, M. Tumor-Associated Macrophages and Mast Cells Positive to Tryptase Are Correlated with Angiogenesis in Surgically-Treated Gastric Cancer Patients. Int. J. Mol. Sci. 2018, 19, 1176. [CrossRef] [PubMed] 
22. Limoge, M.; Safina, A.; Beattie, A.; Kapus, L.; Truskinovsky, A.M.; Bakin, A.V. Tumor-fibroblast interactions stimulate tumor vascularization by enhancing cytokine-driven production of MMP9 by tumor cells. Oncotarget 2017, 8, 35592. [CrossRef] [PubMed]

23. Coppé, J.P.; Kauser, K.; Campisi, J.; Beauséjour, C.M. Secretion of vascular endothelial growth factor by primary human fibroblasts at senescence. J. Biol. Chem. 2006, 281, 29568-29574. [CrossRef] [PubMed]

24. Laforgia, M.; Calabrò, C.; Scattone, A.; Laface, C.; Porcelli, M.; Gadaleta, C.D.; Nardulli, P.; Ranieri, G. Pharmacotherapy in Mast Cell Leukemia. Expert Opin. Pharmacother. 2020, 21, 1059-1069. [CrossRef] [PubMed]

25. Hendrick, M.J.; Goldschmidt, M.H.; Shofer, F.S.; Wang, Y.Y.; Somlyo, A.P. Postvaccinal sarcomas in the cat: Epidemiology and electron probe microanalytical identification of aluminum. Cancer Res. 1992, 52, 5391-5394. [PubMed]

26. Couto, S.S.; Griffey, S.M.; Duarte, P.C.; Madewell, B.R. Feline vaccine-associated fibrosarcoma: Morphologic distinctions. Vet. Pathol. 2002, 39, 33-41. [CrossRef] [PubMed]

27. Powers, B.E.; Hoopes, P.J.; Ehrhart, E.J. Tumor diagnosis, grading, and staging. Semin. Vet. Med. Surg. 1995, 10, $158-167$.

28. Ammendola, M.; Sacco, R.; Marech, I.; Sammarco, G.; Zuccalà, V.; Luposella, M.; Patruno, R.; Giordano, M.; Ruggieri, E.; Zizzo, $\mathrm{N}$; et al. Microvascular density and endothelial area correlate with Ki-67 proliferative index in surgically-treated pancreatic ductal adenocarcinoma patients. Oncol. Lett. 2015, 10, 967-971. [CrossRef]

29. Kanno, A.; Hatori, M.; Hosaka, M.; Kishimoto, K.N.; Watanuki, M.; Watanabe, M.; Itoi, E. Multiple bone metastasis of sclerosing epithelioid fibrosarcoma 12 years after initial surgery-increasing ki-67 labeling index. Sarcoma 2009, 2009, 953750. [CrossRef]

30. Lin, X.Y.; Wang, L.; Zhang, Y.; Dai, S.D.; Wang, E.H. Variable Ki67 proliferative index in 65 cases of nodular fasciitis, compared with fibrosarcoma and fibromatosis. Diagn. Pathol. 2013, 8, 50. [CrossRef]

31. Hendrick, M.J.; Brooks, J.J. Postvaccinal sarcomas in the cat: Histology and immunohistochemistry. Vet. Pathol. 1994, 31, 126-129. [CrossRef] [PubMed]

32. Ranieri, G.; Labriola, A.; Achille, G.; Florio, G.; Zito, A.F.; Grammatica, L.; Paradiso, A. Microvessel density, mast cell density and thymidine phosphorylase expression in oral squamous carcinoma. Int. J. Oncol. 2002, 21, 1317-1323. [CrossRef] [PubMed]

33. Ranieri, G.; Passantino, L.; Patruno, R.; Passantino, G.; Jirillo, F.; Catino, A.; Mattioli, V.; Gadaleta, C.; Ribatti, D. The dog mast cell tumour as a model to study the relationship between angiogenesis, mast cell density and tumour malignancy. Oncol. Rep. 2003, 10, 1189-1193. [CrossRef] [PubMed]

34. Weidner, N.; Semple, J.P.; Welch, W.R.; Folkman, J. Tumor angiogenesis and metastasis-correlation in invasive breast carcinoma. N. Engl. J. Med. 1991, 324, 1-8. [CrossRef] [PubMed]

35. Ammendola, M.; Sacco, R.; Sammarco, G.; Donato, G.; Montemurro, S.; Ruggieri, E.; Patruno, R.; Marech, I.; Cariello, M.; Vacca, A.; et al. Correlation between serum tryptase, mast cells positive to tryptase and microvascular density in colo-rectal cancer patients: Possible biological-clinical significance. PLoS ONE 2014, 9, e99512. [CrossRef] [PubMed]

36. Ammendola, M.; Marech, I.; Sammarco, G.; Zuccalà, V.; Luposella, M.; Zizzo, N.; Patruno, R.; Crovace, A.; Ruggieri, E.; Zito, A.F.; et al. Infiltrating mast cells correlate with angiogenesis in bone metastases from gastric cancer patients. Int. J. Mol. Sci. 2015, 16, 3237-3250. [CrossRef] [PubMed]

37. Ammendola, M.; Patruno, R.; Sacco, R.; Marech, I.; Sammarco, G.; Zuccalà, V.; Luposella, M.; Zizzo, N.; Gadaleta, C.; Porcelli, M.; et al. Mast cells positive to tryptase and tumour-associated macrophages correlate with angiogenesis in locally advanced colorectal cancer patients undergone to surgery. Expert Opin. Ther. Targets 2016, 20, 533-540. [CrossRef]

38. Ranieri, G.; Ammendola, M.; Patruno, R.; Celano, G.; Zito, F.A.; Montemurro, S.; Rella, A.; Di Lecce, V.; Gadaleta, C.D.; Battista De Sarro, G.; et al. Tryptase-positive mast cells correlate with angiogenesis in early breast cancer patients. Int. J. Oncol. 2009, 35, 115-120. [CrossRef]

39. Lyu, H.G.; Haider, A.H.; Landman, A.B.; Raut, C.P. The opportunities and shortcomings of using big data and national databases for sarcoma research. Cancer 2019, 125, 2926-2934. [CrossRef]

40. Wibmer, C.; Leithner, A.; Zielonke, N.; Sperl, M.; Windhager, R. Increasing incidence rates of soft tissue sarcomas? A populationbased epidemiologic study and literature review. Ann. Oncol. 2010, 21, 1106-1111. [CrossRef]

41. Folpe, A.L. Fibrosarcoma: A review and update. Histopathology 2014, 64, 12-25. [CrossRef] [PubMed]

42. Miwa, S.; Yamamoto, N.; Hayashi, K.; Takeuchi, A.; Igarashi, K.; Tsuchiya, H. Therapeutic Targets for Bone and Soft-Tissue Sarcomas. Int. J. Mol. Sci. 2019, 20, 170. [CrossRef] [PubMed]

43. Cannon, C.M. Cats, Cancer and Comparative Oncology. Vet. Sci. 2015, 2, 111-126. [CrossRef] [PubMed]

44. Gordon, I.; Paoloni, M.; Mazcko, C.; Khanna, C. The Comparative Oncology Trials Consortium: Using Spontaneously Occurring Cancers in Dogs to Inform the Cancer Drug Development Pathway. PLoS Med. 2009, 6, e1000161. [CrossRef]

45. Paoloni, M.C.; Khanna, C. Comparative oncology today. Vet. Clin. N. Am. Small Anim. Pract. 2007, 37, 1023-1032. [CrossRef]

46. Ranieri, G.; Gadaleta, C.D.; Patruno, R.; Zizzo, N.; Daidone, M.G.; Hansson, M.G.; Paradiso, A.; Ribatti, D. A model of study for human cancer: Spontaneous occurring tumors in dogs. Biological features and translation for new anticancer therapies. Crit. Rev. Oncol. Hematol. 2013, 88, 187-197. [CrossRef]

47. Marech, I.; Gadaleta, C.D.; Ranieri, G. Possible prognostic and therapeutic significance of c-Kit expression, mast cell count and microvessel density in renal cell carcinoma. Int. J. Mol. Sci. 2014, 15, 13060-13076. [CrossRef]

48. Schiffman, J.D.; Breen, M. Comparative oncology: What dogs and other species can teach us about humans with cancer. Philos. Trans. R. Soc. Lond. Ser. Biol. Sci. 2015, 370. [CrossRef] 
49. Marech, I.; Ammendola, M.; Leporini, C.; Patruno, R.; Luposella, M.; Zizzo, N.; Passantino, G.; Sacco, R.; Farooqi, A.A.; Zuccalà, V.; et al. C-Kit receptor and tryptase expressing mast cells correlate with angiogenesis in breast cancer patients. Oncotarget 2018, 9, 7918-7927. [CrossRef]

50. Ammendola, M.; Sacco, R.; Sammarco, G.; Donato, G.; Zuccalà, V.; Romano, R.; Luposella, M.; Patruno, R.; Vallicelli, C.; Verdecchia, G.M.; et al. Mast Cells Positive to Tryptase and c-Kit Receptor Expressing Cells Correlates with Angiogenesis in Gastric Cancer Patients Surgically Treated. Gastroenterol. Res. Pract. 2013, 2013, 703163. [CrossRef]

51. Zhang, Y.; Li, L.; Zou, S.; Wang, C.; Xun, J. Clinicopathological implications of VEGF/VEGFR2 expression and microvessel density in soft tissue sarcoma. Int. J. Clin. Exp. Med. 2017, 10, 13500-13508.

52. Yudoh, K.; Kanamori, M.; Ohmori, K.; Yasuda, T.; Aoki, M.; Kimura, T. Concentration of vascular endothelial growth factor in the tumour tissue as a prognostic factor of soft tissue sarcomas. Br. J. Cancer 2001, 84, 1610-1615. [CrossRef] [PubMed]

53. Cao, Y.; O’Reilly, M.S.; Marshall, B.; Flynn, E.; Ji, R.W.; Folkman, J. Expression of angiostatin cDNA in a murine fibrosarcoma suppresses primary tumor growth and produces long-term dormancy of metastases. J. Clin. Investig. 1998, 101, 1055-1063. [CrossRef] [PubMed]

54. Chao, C.; Al-Saleem, T.; Brooks, J.J.; Rogatko, A.; Kraybill, W.G.; Eisenberg, B. Vascular endothelial growth factor and soft tissue sarcomas: Tumor expression correlates with grade. Ann. Surg. Oncol. 2001, 8, 260-267. [CrossRef]

55. Ranieri, G.; Ammendola, M.; Marech, I.; Laterza, A.; Abbate, I.; Oakley, C.; Vacca, A.; Sacco, R.; Gadaleta, C.D. Vascular endothelial growth factor and tryptase changes after chemoembolization in hepatocarcinoma patients. World J. Gastroenterol. 2015, 21, 6018-6025. [CrossRef]

56. Patruno, R.; Arpaia, N.; Gadaleta, C.D.; Passantino, L.; Zizzo, N.; Misino, A.; Lucarelli, N.M.; Catino, A.; Valerio, P.; Ribatti, D.; et al. VEGF concentration from plasma-activated platelets rich correlates with microvascular density and grading in canine mast cell tumour spontaneous model. J. Cell. Mol. Med. 2009, 13, 555-561. [CrossRef]

57. Zizzo, N.; Patruno, R.; Zito, F.A.; Di Summa, A.; Tinelli, A.; Troilo, S.; Misino, A.; Ruggieri, E.; Goffredo, V.; Gadaleta, C.D.; et al. Vascular endothelial growth factor concentrations from platelets correlate with tumor angiogenesis and grading in a spontaneous canine non-Hodgkin lymphoma model. Leuk. Lymphoma 2010, 51, 291-296. [CrossRef]

58. Ranieri, G.; Coviello, M.; Patruno, R.; Valerio, P.; Martino, D.; Milella, P.; Catalano, V.; Scotto, F.; De Ceglie, A.; Quaranta, M.; et al. Vascular endothelial growth factor concentrations in the plasma-activated platelets rich (P-APR) of healthy controls and colorectal cancer patients. Oncol. Rep. 2004, 12, 817-820. [CrossRef]

59. Ranieri, G.; Laface, C.; Laforgia, M.; De Summa, S.; Porcelli, M.; Macina, F.; Ammendola, M.; Molinari, P.; Lauletta, G.; Di Palo, A.; et al. Bevacizumab Plus FOLFOX-4 Combined With Deep Electro-Hyperthermia as First-line Therapy in Metastatic Colon Cancer: A Pilot Study. Front. Oncol. 2020, 10, 590707. [CrossRef]

60. Jang, H.K.; Kim, B.S.; Han, J.; Yoon, J.K.; Lee, J.R.; Jeong, G.J.; Shin, J.Y. Therapeutic angiogenesis using tumor cell-conditioned medium. Biotechnol. Prog. 2016, 32, 456-464. [CrossRef]

61. Hanyu, A.; Kojima, K.; Hatake, K.; Nomura, K.; Murayama, H.; Ishikawa, Y.; Miyata, S.; Ushijima, M.; Matsuura, M.; Ogata, E.; et al. Functional in vivo optical imaging of tumor angiogenesis, growth, and metastasis prevented by administration of anti-human VEGF antibody in xenograft model of human fibrosarcoma HT1080 cells. Cancer Sci. 2009, 100, 2085-2092. [CrossRef] [PubMed]

62. Lee, H.-J.; Kim, S.-A.; Lee, H.-J.; Jeong, S.-J.; Han, I.; Jung, J.H.; Lee, E.-O.; Zhu, S.; Chen, C.-Y.; Kim, S.-H. Paeonol Oxime Inhibits bFGF-Induced Angiogenesis and Reduces VEGF Levels in Fibrosarcoma Cells. PLoS ONE 2010, 5, e12358. [CrossRef] [PubMed]

63. Mori, A.; Arii, S.; Furutani, M.; Hanaki, K.; Takeda, Y.; Moriga, T.; Kondo, Y.; Gorrin Rivas, M.J.; Imamura, M. Vascular endothelial growth factor-induced tumor angiogenesis and tumorigenicity in relation to metastasis in a HT1080 human fibrosarcoma cell model. Int. J. Cancer 1999, 80, 738-743. [CrossRef]

64. Ranieri, G.; Patruno, R.; Ruggieri, E.; Montemurro, S.; Valerio, P.; Ribatti, D. Vascular endothelial growth factor (VEGF) as a target of bevacizumab in cancer: From the biology to the clinic. Curr. Med. Chem. 2006, 13, 1845-1857. [CrossRef]

65. Eisenthal, A.; Schwartz, I.; Issakov, J.; Klausner, Y.; Misonzhnik, F.; Lifschitz-Mercer, B. Immunohistochemistry Evaluation of the Effect in Vivo of Tumor Necrosis Factor (TNF)-alpha on Blood Vessel Density in Murine Fibrosarcoma. Sarcoma 2003, 7, 57-61. [CrossRef]

66. Nissen, L.J.; Cao, R.; Hedlund, E.M.; Wang, Z.; Zhao, X.; Wetterskog, D.; Funa, K.; Bråkenhielm, E.; Cao, Y. Angiogenic factors FGF2 and PDGF-BB synergistically promote murine tumor neovascularization and metastasis. J. Clin. Investig. 2007, 117, 2766-2777. [CrossRef]

67. Gadbail, A.R.; Hande, A.; Chaudhary, M.; Nikam, A.; Gawande, M.; Patil, S.; Tekade, S.; Gondivkar, S. Tumor angiogenesis in keratocystic odontogenic tumor assessed by using CD-105 antigen. J. Oral Pathol. Med. 2011, 40, 263-269. [CrossRef]

68. Sharma, S.G.; Aggarwal, N.; Gupta, S.D.; Singh, M.K.; Gupta, R.; Dinda, A.K. Angiogenesis in renal cell carcinoma: Correlation of microvessel density and microvessel area with other prognostic factors. Int. Urol. Nephrol. 2011, 43, 125-129. [CrossRef]

69. Hershey, A.E.; Sorenmo, K.U.; Hendrick, M.J.; Shofer, F.S.; Vail, D.M. Prognosis for presumed feline vaccine-associated sarcoma after excision: 61 cases (1986-1996). J. Am. Vet. Med. Assoc. 2000, 216, 58-61. [CrossRef]

70. Rudmann, D.G.; Van Alstine, W.G.; Doddy, F.; Sandusky, G.E.; Barkdull, T.; Janovitz, E.B. Pulmonary and mediastinal metastases of a vaccination-site sarcoma in a cat. Vet. Pathol. 1996, 33, 466-469. [CrossRef] 